\title{
WEALTH ITEMS IN THE WESTERN HIGHLANDS OF WEST PAPUA ${ }^{1}$
}

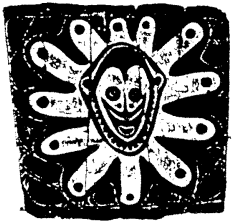

Anton Ploeg

Radboud University, Nijmegen

This article compares the distinctive uses of wealth items among Grand Valley Dani, Western Dani, and Me, the largest ethnic groups in West Papua. The time period covered is primarily from first contact with Europeans to the early 1970s. (Wealth items, inalienability, ancestor cult, exchange)

The Western Highlands of West Papua extend from the Grand Valley of the Baliem to the western tip of the Central Highlands (see map). The area coincides with the "Western Sphere" of the Highlands as identified by Hyndman and Morren (1990). They define a sphere as "a potentially expansive, segmentary, reticulated mosaic of local groups that, notwithstanding observable ethnolinguistic diversity, share a common tradition and are strongly influenced by one or more core populations at the historic-geographic centre of their region" (Hyndman and Morren 1990:10). Hyndman and Morren (1990:13) distinguish three such spheres in the Central Highlands: Eastern, Central, and Western. The Eastern Sphere centers on "a chain of eight valleys from Arona-Aiyura to Tari-Koroba"; the Central on "the Sepik Source Basin and the Sibil valley"; and the Western centers "on the Baliem valley and the Paniai Lakes."

A number of ethnic groups, well represented in ethnographic studies, reside in the Western Highlands of West Papua. Best known are the Grand Valley Dani, the Western Dani, and the Me. The Grand Valley is located in the lower reaches of the Baliem River where it flows southeast through a wide valley with a relatively flat floor before it leaves the Highlands via the Baliem Gorge (see map). The habitat of the Grand Valley Dani is formed by the floor, the slopes of the valley, and its tributary valleys. The habitat of the Western Dani centers on the valleys of the North Baliem, the Boko, north of the Grand Valley, the Toli, the Yamo, and the Ila rivers. They occupy the entire middle section of the Western Highlands north and west of the Grand Valley. In the recent past they pushed further west. As a result, the valleys of the Ila, the upper Kema, the Nogolo, and the Dora have an ethnically mixed population of Western Dani, Damal, Moni, and some smaller groups. The habitat of the Me runs from the middle reaches of the Kema to the westernmost tip of the Highlands. Most Me live around the Paniai, Tigi, and Tage lakes, and in the valley of the Edege River and its tributaries. The Grand Valley Dani, the Western Dani, and the Me are by far the largest Highlands groups, and are the focus of this article. 


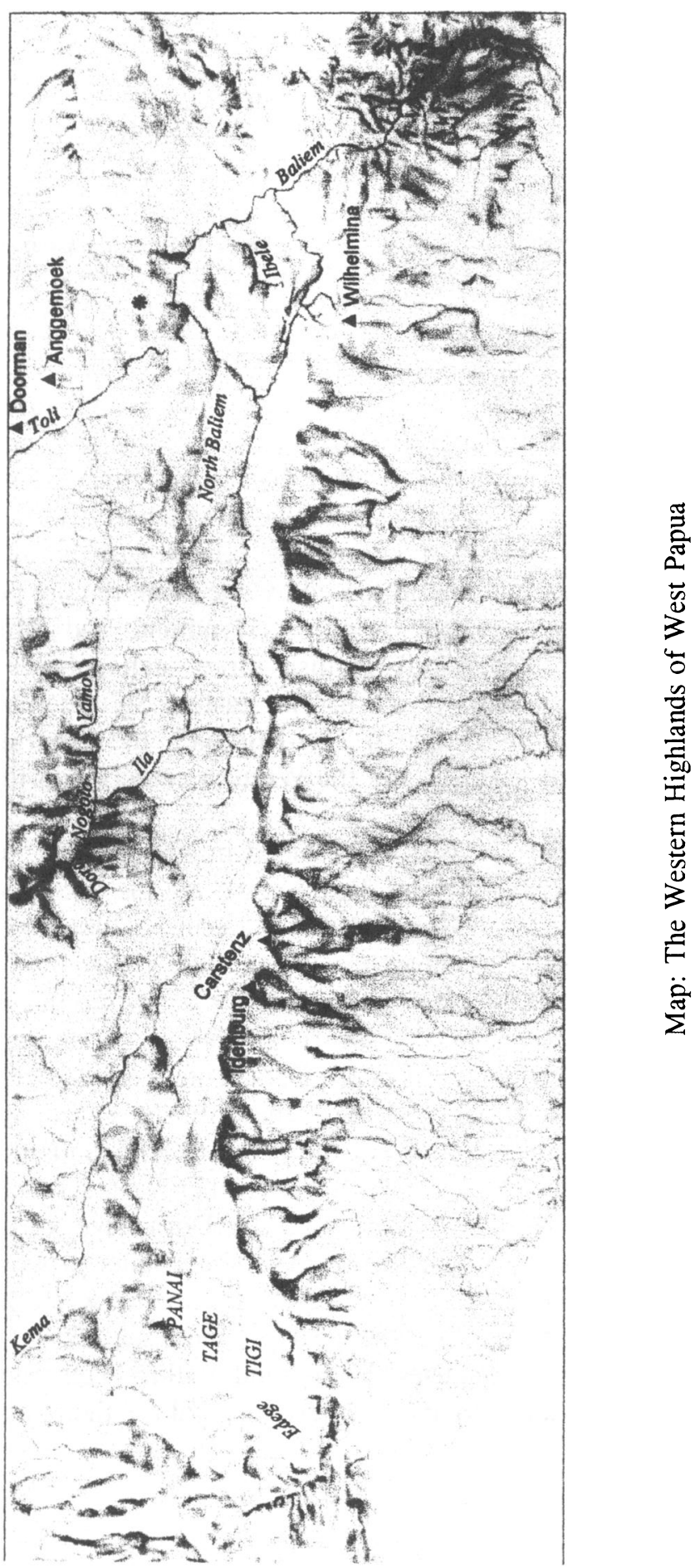




\section{THE ETHNOGRAPHIC RECORD}

The establishment of colonial rule in the West Papua Highlands started in the late 1930s in the Paniai Lakes area. The extension of colonial control was interrupted by World War II. Missionaries and administrative officers settled in the Dani areas in the 1950s, in 1954 in the Grand Valley, and in 1956 among the Western Dani (Hayward 1980:124), and missionaries of various denominations have remained active. In 1963, the Indonesian government took over the administration of the area, and when highlanders appeared to resist it, they were dealt, to all appearances, extremely harsh measures (Defert 1996:ch. 12; Meiselas 2003:142-44). Ethnographic coverage of this incorporation is understandably slight. The Me have been studied by Pospisil $(1958,1963,1978,1989)$, who referred to the people as the Kapauku, more recently by Hylkema, a Franciscan missionary and self-taught ethnographer, and by Giay (1995), himself a Me. Giay is one of the proponents of the name Me rather than Kapauku or Ekagi (Ekari), names still in use. At his death in 1998, Hylkema left behind many monographs and writings in draft, based on his association with the Me that lasted from 1969 to 1994 . I am editing and introducing two incomplete manuscripts that he worked on shortly before his death (Hylkema n.d.a and n.d.b). In addition, there is ethnographic material about the Me by the administrative officers de Bruijn and Dubbeldam, the botanist Eyma, and the medical officers van der Hoeven and Boelen.

Publications on the Western Dani have been made by the missionaries Larson, on Ilaga Dani, and Hayward, who worked in the Mulia area; by Wirz and O'Brien, who worked in the Toli Valley, and by myself on the Wanggulam, in Bokondini. Based on the extensive notes on the North Baliem Western Dani written by the missionary-linguists Norman and Sheila Draper, Szalay (1999) has written a comparative thesis on West Papua Highlands ethnography. Finally, Pierre and AnneMarie Pétrequin have researched production, use, and significance of stone artifacts in the Highlands. Their work includes discussion of stone wealth items. Long-term field research among the Grand Valley Dani has been carried out by Heider, Broekhuyse, the missionary/anthropologist Peters, and recently, by Butt and Hampton. Heider (1970:300-01) worked in the northeast of the valley, Broekhuyse in the same area and in the southeast, while Peters (1967:18-20) collected most of his data in an eastern side valley of the Baliem. Hampton's (1999:xviii-xxii) report refers to the area where Heider worked. Butt (1998:51-52) worked west of the Baliem. To what extent these ethnographies represent the way of life of all, or most, Grand Valley Dani over the last 40 years is not clear.

Most of the research by anthropologists was carried out in the 1950s and early 1960s, when the Dutch administered West Papua. An exception is Wirz, who worked in the Toli Valley in 1921. Consequently, most of this work refers to an era shortly before or shortly after the imposition of colonial control; it reflects theoretical concerns that have since become less urgent and was often done with imperfect knowledge of the vernacular languages. The shortage of recent research prevents 
understanding about present-day usage and how the use of wealth items changed between colonial and postcolonial times. In several instances, people have stopped using the artifacts discussed here.

Ethnographic information about the Papua New Guinea Highlands is many times greater than that for the Highlands of West Papua. Moreover, it is theoretically far more sophisticated. However, this discrepancy allows me to use theoretical models and concepts generated to analyze Papua New Guinea Highlands ways of life for the subject of the present essay: comparing how the Me, the Western Dani, and the Grand Valley Dani used their wealth items. Specifically, this essay uses Godelier's (1982, 1991) model of the transformation of Great Man to Big Man societies as a general guide. Godelier's transformation model, elaborated by Lemonnier (1990), posits differential processes of sociocultural change leading toward the late precolonial Great Man and Big Man "social logics." The discussion of this model by, among others, Lederman (1991) and Wiessner and Tumu (1998) has pointed to a greater variety of pathways of change than Godelier at first envisioned. The data from the Western Highlands of West Papua presented in this article add to this variety. But the data that enable constructing models of sociocultural change in the Papua New Guinea Highlands are largely absent for West Papua.

The term "wealth items" refers to movable objects, accorded great value and used as means of payment, as gifts, as ritual objects, and as markers of identity. I turn first to the Me, then the Western Dani, and third to the Grand Valley Dani, using this order because the Grand Valley Dani are the most distinctive in their use of wealth items, compared to other Highlands groups, both in West Papua and in Papua New Guinea.

\section{ME}

The Me had a persistent mistrust of and opposition to foreigners (ogai), whether Dutch or Indonesian, government people or missionaries. While Me interacted with them, they maintained their own world. During Dutch rule, there were three uprisings; in the last, in 1956, the colonial administration deployed its marines (van Baal 1989:532-34; Giay 1995:47-51). Proselytizing met with little success until local trainees started to spread the gospel (Giay 1995:31). A Me catechist set up an alternative church, based on reinterpreted Christian doctrine, that attracted a large following (Giay 1995).

Pospisil worked among the Me in the Kamu area, the valleys of the upper Edege and its tributaries, west of the three Paniai lakes, first in 1954-55, before a patrol post had been established there (Pospisil 1958:4, 65). Hylkema (2002) claims that the Me should be divided into three cultural groups: the people around the Paniai and Tage lakes, those near Lake Tigi and in the Kamu area, and those living further west and northwest at the fringes of the Highlands. Hylkema calls these people the Mapia $\mathrm{Me}$, and believes that in the late precolonial era they were gradually becoming ethnically different from the Me further east. Hence, Pospisil's data pertain to the 
Kamu-Tigi Me, less to the Paniai-Tage Me, and probably much less to the Mapia Me. Hylkema's data on wealth items deal primarily with the Paniai-Tage and the Kamu-Tigi Me.

\section{Wealth Items}

The primary wealth items among Paniai-Tage and Kamu-Tigi Me were cowrie and nassa shells and pigs (Pospisil 1963:301, 1978:18; Hylkema n.d.a). Shells had to be included in bridewealth (Pospisil 1963:204, 212; Hylkema n.d.b: ch 2), but the two authors differ about the inclusion of pigs. Pospisil (1963:212) says that "at least" one pig must be included; but Hylkema has collected only a few cases that included pigs. These cases concerned the Kamu-Tigi area, which for Hylkema are culturally separate, so the discrepancy is likely the result of cultural divergence. Cowries drew the greatest attention. They came by trade from the coast, which limited their availability. While Pospisil (1963:308) located their origin on the south coast, according to Hylkema (n.d.a), they reached the Me from the north. ${ }^{2}$ Moreover, following Dubbeldam (1964:299), Hylkema (n.d.a) opines that the cowry supply increased sharply in the recent past due to the intensification of bird-of-paradise hunting in the area north of the Me habitat. While he offers regrettably little evidence for this view, it seems plausible, given the settlement of Dutch in the Cenderawasih Bay area since 1856 and the resulting increase in trade (Rutherford 2003:183-88; see also Ellen 2003:134-47).

Hughes (1977), who conducted field research in the central parts of what became Papua New Guinea, investigating the indigenous trade that had taken place in the early twentieth century, favors the process hypothesized by Hylkema. Hughes (1977:198-202) concludes that during the period before Europeans entered the Highlands, the import of goods, including cowries, had increased greatly there. Moreover, more cowries were traded in from the north rather than from the south (Hughes 1977:187-88).

The Me graded cowries into categories and subcategories based on size, shape, and color, and further distinguished between old cowries (traded before colonial incorporation) and those imported by colonial newcomers. The categories differed widely in value, with the recently imported ones less valuable. Pospisil (1963:301-04) writes that the Me in the Kamu area in the mid 1950s distinguished five categories of old cowries, with a value differential of over 300 or more, often expressed in multiples of six, in accordance with the Me sexagesimal counting system (Pospisil 1989:20). Dubbeldam, an administrative officer among the Me in the Paniai area around 1960 (Watson 1964:vi), reports a slightly different gradation of cowrie denominations, with another series of names. Moreover, cowries became smoother with use, and so acquired more value. Hylkema (2002:235) writes that Me had designed yet another set of refined criteria on the basis of which each separate shell could be differentiated within its own category. Assigning specific cowries to their appropriate categories and subcategories required expertise which few people, 
apparently always men, attained (Hylkema n.d.a). Hylkema gives the impression that their rulings were contested. The fact that a cowrie had been successfully used in a transaction provided an alternative testimony of its value (Hylkema 2002:235).

As long as cowries had to be acquired from other Papuans, their number remained limited. A further restriction on the number of shells was that those in the middle categories were on a string that in time tended to damage them (Pospisil 1963:308). With colonial incorporation, large numbers of shells were imported, especially into the Paniai area, the center of administrative activities. In keeping with their mistrust of the newcomers, the Me started distinguishing between old and newly imported cowries (Robbins and Akin 1999:24). By such means, they succeeded in letting the old ones retain their value into the 1970s (Hylkema n.d.a). Some Me attempted to counterfeit old shells by frequently wearing those introduced by the colonial newcomers (Pospisil 1963:301, 304, 338; Dubbeldam 1964:302; Giay 1995:38-40). In 1969, the year that Hylkema started work among the Me, the scope for cowrie transactions had increased due to increased importation by foreigners. This made it easier for women to acquire cowries even though men claimed that managing cowries pertained to them. Hylkema (n.d.a) observed that men were sometimes taken aback by the high-quality cowries that women owned.

Hylkema (n.d.a) argues that over time, the Me shifted their categorizations and evaluations of cowries. The further from Paniai, his supposed point of entry, the more valuable were the categories. Hylkema's insights explain the differences between the categorizations reported at almost the same time by Pospisil for the Kamu Me and by Dubbeldam for the Paniai Me. Moreover, they assert that the steady import of cowries was a novelty to the Me, which is in line with the people's intense preoccupation with these shells and with their grading. Discussing Melanesian currencies, Foster (1999:230-01) concludes, "Money forms will always be subject to skeptical reception, an awareness that these harbor within them unrevealed possibilities for the future, hidden agencies and identities that might be exploited or might engender exploitation in as yet unimagined ways." This is precisely how the Me perceived their cowries.

Apart from cowries, some types of nassa-shell necklaces were used as valuables, especially as part of bridewealth. Pospisil (1963:304) regards both cowries and the shorter nassa necklaces as money. At the time of his first field research, necklaces of tiny (one- to four-milimeter), multicolored glass beads also served as money (Pospisil 1963:304), but Hylkema (n.d.a) writes that they were no longer in use when he arrived among the Me in 1969. Pospisil, quoting Umbreit, Elgin, and Kinter (1948), defines money as "the common medium of exchange and the common measure of value." He subsequently points to the very wide range of goods that the Me could purchase with cowries, and their habit of expressing the value of goods in terms of cowries (Pospisil 1963:301). At the same time these objects show the features that Godelier (1996:222-26, 1999) associates with "objects précieux" (wealth items). First, Godelier points to their uselessness in productive activities and in everyday life; second, to their abstraction, by which he means that these objects are 
taken out of their previous context and can thus be resignified ${ }^{3}$; and third, to the beauty that people perceive in them.

Me valuables appear to conform to the definition of money as given by Umbreit and his collaborators. Moreover, Giay (1995:20) and Breton (1999) have followed Pospisil's usage, with the provisos that Giay's statement refers to the 1950s, when Me had been exposed to European influences for two decades, and Breton based his view from fieldwork among the Wodani, in the mid 1990s. Nonetheless, it seems useful to add what kind of money was used. Shells, shell strings, and shell necklaces seem to have been coins, or assemblages of coins. These were valuables in their own right, as opposed to most present-day coins, whose metal value is a fraction of their face value. Shell items lacked the anonymity of present-day coins. Among the Me, there was no immaterial money like bank accounts, nor were there drawing rights on banks or financial institutions, the usual form of bank credit. Hence, the supply of money was limited. In Western monetary systems, material money is being used decreasingly and immaterial money increasingly (Klamer and van Dalen 1998). But given the Me's preoccupation with the physical properties of their cowries, such a development is unlikely to have taken place among them, had the colonial powers not intervened.

What further distinguished Me cowries from money used in the Western world is that precious cowries had to be included in bridewealth prestations (Hylkema n.d.b:ch.2). This suggests that the amount in itself was not critical, but that the quality of the shells also mattered (cf. Gregory 1982:49). Moreover, Hylkema (2002:235) states that the strings held shells of various values. This suggests again that numbers alone were insufficient, unlike Western money. From what Hylkema writes, it seems that the strings were a megavaluable, and that the constituent shells were withdrawn from circulation. ${ }^{4}$

\section{Capitalism}

Pospisil's insistence that the Kamu Me employed money is part of his wider argument that they ran a capitalist economy. Several features of their way of life prompted him to use this characterization: people, especially men, were after the accumulation of cowries, of money. Pospisil calls them "businessmen" (Pospisil 1963:333, 1978:21). Sometimes he puts the word in the mouth of his Me spokesmen (Pospisil 1978:30). Hylkema employs this term also (2002:235). Wealth differences were considerable, and when men co-operated, their individual contributions to the co-operative projects remained, as Pospisil (1978:31) remarks, "readily perceivable and separable from [those] of others." Sales, in exchange for cowries, of a wide range of goods played the most important part in circulation. Prices fluctuated depending on supply and demand. Barter did not occur much and gifts were unknown. But what Pospisil (1963:31) means by gifts, "a giving without expectation of approximately equal reciprocation," differs sharply from definitions of Mauss and others, notably Godelier. 
The social institution that drew the greatest number of participants, and which required the longest and most laborious preparations, was a pig feast initiated by a wealthy pig-owner and co-sponsored by other pig-owners, culminating in a massive sale of pork and other goods for cowries (Pospisil 1963:327-31; de Bruijn 1978:17173). During these feasts many Me joined in and offered goods for sale. Kamu Me economy deviated from Western capitalism in what Pospisil, inspired by Veblen, calls its "conspicuous generosity" (Pospisil 1963:361):

Generosity might take the form of loans, or lavish distributions of food free of charge on such occasions as birth ceremonies or [the ceremony] on the opening day of the sequence of dances connected with a pig feast. There exists almost a compulsion for extensions of credit in this native society. In some regions, such as that of the Paniai Lake, rich people who prove to be stingy with their credits are even punished by execution. (Pospisil 1963:31)

By being generous, Me men acquired followers: a person's debtors were his "stoutest supporters" (Pospisil 1978:50-51). Status and kin considerations influenced the operation of the law of supply and demand on price formation. But Gregory (1982:51) regards Pospisil's "conspicuous generosity" as evidence that his statements about Me capitalism are a "profound misunderstanding," pointing to the prevalence of gift relationships, which seems correct, if we allow for the fact that people were often pressured into gifting.

Although Pospisil does not use the term Big Man and does not touch greatly upon the ethnography of the Papua New Guinea Highlands, his data make it clear that Kamu Me leaders operated in polities pervaded by, in Godelier's (1982, 1991) expression, a Big Man logic. Giay (1995:21-22) implicitly acknowledges this by quoting Strathern's (1971) characterization of Melpa leadership while describing Me leaders.

\section{Alienability/Inalienability}

Before dealing with the matter of inalienable wealth items among the Me, I mention several modalities of inalienability as they occur more in general. One form is that movable or immovable objects cannot or may not be transferred by their owner or owners in the course of their lifetime. At death these objects go to the heirs. Another modality is that such objects cannot be transferred to people viewed as outsiders, such as members of other kin groups, other polities, etc. Yet another is that objects, although they are transferable to others, inescapably retain aspects that link them to their former owner(s), holder(s), and/or maker(s). A fourth modality that has not been reported for the West Papua Highlands is that an object is disposed of together with its owner when he or she dies, as among the Melpa (Strathern 1971:191-92).

The above discussion of Kamu Me wealth items shows that shells were freely transferred to others, and that they gradually increased in value, which transformed them into treasured old shells. They thus acquired an identity that one might call 
inalienable. Moreover, necklaces of a specific type, decorated with dogs' teeth, nassa shells, and cowries, were "usually regarded as heirlooms, inherited in the main line," presumably the male line (Pospisil 1963:275-76, 1958:201). Pospisil never mentions objects, sacred or not, held by individuals, and denies the existence of shared property among the Kamu Me (1958:115), which might have given them identity in the perception of outsiders and which, as Weiner (1992) and Godelier (1999:36) argue, shored up the exchanges in which these individuals engaged.

\section{Trade or Gift Exchange}

Were Me transactions carried out to make a profit, as in a capitalist economy, or were they gifts and part of a larger chain of transactions entailed by and adding to a new or existing relationship? Pospisil is only partly clear about this. From what he says about the organization of the pig feast, and even more about what he calls the "pig market" (Pospisil 1963:333), it seems that at least some transactions were chance events. However, this information suggests that others were not. The same hybrid impression is created by Boelen's (n.d.:5, 216) description of pig feasts, which is probably based on observations made in the Paniai area in the early 1950s, when Boelen was posted there.

The pig feast proper is more like a fair. The pigs are tied to poles, on show. Two by two, the men withdraw very secretively to talk business. They discuss which piece of pork one of them will buy and what it should cost. The prospective buyer tries to sell the pork to others in smaller quantities and calculates if he can get a small profit. The person who has secured a smaller piece, tries in his turn to hawk it and explores whether it will bring him a few shells to complement the bridewealth which his son needs, or to buy himself a new penis gourd or a skirt, for his wife. . . All this, while the animal concerned is still grunting at its pole. (Boelen n.d.:167-68)

Such negotiations were held after buyers and sellers might have met the previous weeks at the dances held in the dance house on the feasting ground. While Pospisil (1963:333) writes that pig feasts were not frequent, Boelen (n.d.:172) stresses their frequency, especially in the Paniai area, and the large numbers of attendants, so people were likely to meet repeatedly and may have transacted again and again. Hylkema's observations from 1969 agree in part with those of Boelen. He seems to deny the frequency of reselling, but observes that pig feasts were often held in quick succession and that organizing a feast challenged other prominent men to organize one. Most exchanges were with kin or affines, so were likely often repeated. Yet after a seller had laid out portions of pork for sale, prospective buyers approached him from behind, offering a cowrie without revealing who they were. The seller was entitled to refuse the shell or to offer a smaller portion of pork than he had originally laid out. Hylkema describes this process as a contest with one winner and one loser. While Pospisil, as mentioned above, stresses the value that Me put on generosity, Hylkema points out that, at least in cowrie transactions, there was a lot of "pressure for generosity" (Peterson 1993:860). ${ }^{5}$ Similarly, the main assemblers of a bridewealth payment aggressively exhorted their fellow contributors to increase their contribu- 
tions. What remains unclear, however, is whether the organizer of a pig feast pressured men on whom he had a claim to bring pigs to his feast. It would have been plausible for him to do so, since the more pigs slaughtered for the feast, the more impressive the occasion (Hylkema 1974:58).

I believe that during the Me pig feasts a variety of transactions took place: gifts, reciprocating earlier gifts but deviating from the Maussian model in that the partners in the relationship could refuse gifts and press for more; transactions for profit; and transactions which, during ensuing interactions, turned out to be the beginning of a gift relationship. An analogy might be the hybrid character of kula encounters, as described by Uberoi (1962:ch. 8) and by Campbell (1983:203) for the southern Trobriands. Campbell, moreover, points to another similarity between kula encounters and Me pig feasts; namely, the "fun and play" aspect.

\section{WESTERN DANI}

The Western Dani form the largest ethnic group in West Papua. Most recently, Hayward (1997:7) estimated their number at 134,000, slightly more than Silzer and Heikkinen Clouse's (1991:19) estimate of 119,000. Their habitat is formed by Vshaped valleys stretching from the Grand Valley of the Baliem westward beyond the Ila Valley and northward to the fringes of the Highlands.

At the beginning of the colonial era the Western Dani were expanding out of the North Baliem Valley into valleys to its north and west (O'Brien 1969b:24; van Rhijn 1969:52; Hayward 1997:10; Larson 1986:318-21). In the absence of prehistoric research, it has remained unclear when or where these migrations started. Western Dani oral traditions have their ancestors originating in the southeast of the Grand Valley (Larson 1986:11; Hayward 1997:26, 279). Because Western Dani speak mutually understandable dialects, it is most plausible that their ancestors once formed a single group. The cultural differences noted by the ethnographers have then to be explained by residence in separate valleys, mitigated and complicated by encounters with earlier inhabitants and by the adoption of cultural traits due to migrations and possibly by contacts with other ethnic groups.

Around 1960, strikingly soon after missionaries had settled among the Western Dani, and before anthropologists had started field research there, the people began converting en masse to Christianity. They abandoned or destroyed, first, objects with religious significance, including ancestral stones. This was followed in Bokondini and Konda, and possibly other Dani groups, by discarding the polished stones that they had used as wealth objects (O'Brien and Ploeg 1964:287-88). Cowries and cowrie bands remained longer in use. As a result of the early conversion, there are no thorough descriptions of the pagan Western Dani religion, or religions, and of the artifacts used therein. In due course, Western Dani at Mulia, Bokondini, and probably elsewhere much reduced the size of bridewealth payments, and many Mulia Dani argued in favor of their abandonment entirely (Hayward 1997:192). 


\section{Sociocultural Organization}

Before conversion, Western Dani sociocultural organization showed several traits that suggest Godelier's Big Man logic. Polities contained several hundred people (Ploeg 1969; Hayward 1997:5-8), more (Larson 1986:120) or less (O'Brien 1969a:202), and agriculture was intensive. There was an intense exchange of wealth items with life-cycle rites and compensation payments. Yet Western Dani leaders cannot be characterized as Big Men. Leadership among them resulted from a mix of qualifications, with leadership in warfare possibly the most important (Larson 1986:232; Hayward 1980:63-67; O'Brien 1969b:265-76; Ploeg 1969:75-84). Other leadership criteria mentioned are wealth (i.e., the ownership of pigs and other valuables), wives, oratory skill, and supernatural knowledge. Wealth items changed hands during ceremonial events that had to be organized and co-ordinated. The largest ceremonies were compensations for killings and pig feasts. The literature does not indicate that this was done by a special category of leaders, so it seems that war leaders performed these tasks. If so, these leaders resembled those warrior-organizers of exchanges whom Lemonnier (1990), in his analysis of leadership in the eastern half of New Guinea, identified as intermediate between Great Men and Big Men. Lemonnier refers to them as Leaders (1990:ch. 6) or leaders (1991:18-20). If that status includes organizers of wars as well as the community aspect of the exchanges, it characterizes Western Dani leadership.

But the Western Dani did not conform completely to Lemonnier's characteristics. Apart from the people at Tiom and surrounding areas (Draper, pers. comm.; Amonen, in Draper and Draper 1990:213), Western Dani married allies rather than enemies, and there was equality rather than inequality among wife-givers and wifetakers. Among most Western Dani, the important social groups were directed inward. They were centered on two subclans or patrilineages between which preferential marriage relations existed. Marriages occasioned exchanges of wealth items. These Western Dani practiced the delayed exchange of classificatory sisters, combined with marriage payments.

\section{Exchange Items}

Western Dani used a wider range of wealth items than did the Me. These included pigs and pork, oblong polished stones, cowrie shells (both odd shells and shells set in long, narrow, tightly looped bands), slabs of salt, looped carrier bags, and strips of tightly looped thread, often decorated, used in women's skirts (Draper 1958:4; O’Brien 1969b:42-51; Ploeg 1969:10; Hayward 1980:32-34; Larson 1986:127). The term used by the majority of Western Dani for the polished stones is ye. Ye, shells, and salt had to be imported. Ye were obtained from quarries in the northern fringe of the Highlands (Pétrequin and Pétrequin 1993:155). There were salt wells in and near the Western Dani areas, but those preferred were in Ilaga and in the far west, at least until recently outside the Dani area (Pétrequin and Pétrequin 
1993:154; Wakerkwa, in Draper and Draper 1990:245; Yakiya, in Draper and Draper 1990:252; Hayward 1980:29-30; Larson 1986:306-07). ${ }^{6}$

Among the various Western Dani, the relative importance of these items differed. During the first stages of my fieldwork among the Wanggulam, in Bokondini, the ye were the most cherished. They were hidden until needed for an exchange ceremony. Then they were polished with pig grease, fondled, and laid out side by side in a row. Wanggulam had three seemingly unrelated methods to differentiate and evaluate ye. First, they distinguished between those male and female; the males were shorter, more cylindrical, and penile in form, while females were longer, flatter, and often vaguely triangular. When arranging and rearranging a row, men alternated male and female stones. Second, the most valuable stones were given names and were put in the middle of the row. Wedding payments had to include such precious stones. Third, Wanggulam saw a wedding payment as representing the body of the bride, with single ye representing the various body parts.

Second in importance for the Wanggulam were either pigs or looped bands set with cowries. There was an acute "shell hunger" among the Wanggulam when I first arrived in May 1960. (Draper [1958:7] reported a similar phenomenon among the North Baliem Dani at Tiom.) Many Wanggulam offered to work for me or to sell food or artifacts to get cowries. On occasion, the Wanggulam used odd cowries in what seemed commercial transactions with each other. But the usual "biography" (Kopytoff 1986) of a cowrie was to have its back removed and then attached to a looped band and used as a gift in ceremonial transfers of wealth. On these occasions, the bands set with shells were displayed by putting them on the row of ye, in the direction of the row.

After the Western Dani had converted, Wanggulam put little effort into raising pigs. A household, typically an elementary family, might own one to three adult pigs, rarely more. It seems they were not keen to increase their number, since many piglets were killed and eaten by the owning household. Perhaps this was due to the context in which I did my fieldwork, since people were preoccupied with a revitalization movement (O'Brien and Ploeg 1964). Moreover, there were no plans to assemble a compensation payment or hold a pig feast, so people may have seen no need to expand their herds. After the Western Dani had converted to Christianity, missionaries attempted to promote the celebration of Christmas by combining it with a pig feast (O'Brien 1969b:65), and at Mulia the Dani consumed "hundreds" of pigs at Christmas celebrations (Hayward 1997:178-79). But Larson (1986:34) reports that in Ilaga such celebrations "are now giving way to Dani markets at which pork is sold for cash rather than distributed reciprocally between individuals and groups."

The decorated, looped carrier bags and the string used for women's skirts were used as gifts during the first part of a wedding, when the bride was dressed in a ceremonial skirt, consisting in part of the balls of string brought along by female participants. The bride stood holding a horizontal bar tied to two poles, while women wound string around her hips, fashioning it into a skirt. Later that day the bride distributed the bags. 
Ye were distributed by men and apparently kept by men until they were needed. Women might carry them in a carrier bag to a wealth transfer, but I never saw women cherish them as men did. Cowries were handled and used both by men and women for trading. Both men and women were immensely interested in acquiring them. Hence, although the bands to which they were tied were looped by men, and although during a transfer the bands, like the ye, were distributed by men, cowries were less of a male domain than the ye. This also held for pigs, which were cared for more by women than by men. In contrast, the carrier bags and the looped string pertained primarily to women: they were made and used by women, although men may have gathered the raw materials. During a wedding, there was a clear division, with men transacting with men and women with women.

Most of the Western Dani seem to have used the same wealth items as the Wanggulam (Draper 1958:4; Larson 1986:127; Hayward 1997:141). While the Konda Valley Dani did use ye, O'Brien (1969b:408) writes that in Kuttime, and in Kanggime, both located west of the Konda, in the upper reaches of the Toli River, ye were not used, but Wirz (1924:64-66) reports their occurrence in the lower Toli Valley in 1921. O'Brien (1969b) writes that ye were not used in the Yamo, but this statement may refer to the upper Yamo only, since Hayward (1997:141) writes that "sacred stones" were part of Mulia Dani wedding payments. In their study of stone artifacts in West Papua, the Pétrequins (1993:208) report that in the North Baliem only the female-type ye is found. In seeming agreement with this report, Larson (1986) does not mention the distinction in his discussion of Ilaga wealth payments. As for shells, Draper (1958:7) states that at Maki in the lower North Baliem, cowries were not in demand, with people using nassa shells and imported beads instead.

\section{Wedding Payments}

Among most Western Dani there were three wedding payments: first, a betrothal payment; second, a payment assembled by the bride's father and transferred to his wife's relatives (called uak); and third, bridewealth, assembled by the groom's father on the occasion of a wedding and transferred to the bride's father. The bridewealth had at least to equal the uak, and the uak in turn had to be at least equal to the uak for the bride's mother. Thus the payments were linked across the generations. They were not competitive or "agonistic" (Mauss 1990:7; Godelier 1996:57). The lack of competitiveness is a strong reason for arguing that Western Dani did not follow a Big Man logic. In line with this view is that assembling and distributing wedding payments caused wealth items to change hands within the community. Similarly, the pigs slaughtered during weddings were often consumed primarily by community members, suggesting a degree of inalienability about these items. But alienability existed with regard to the most precious ye, since people might remember their transactions and who gave which to whom. 


\section{Rating of Wealth Items}

The composition of wedding payments among Western Dani groups suggests differences in the rating of wealth items. I refer here to wedding payments only because most of the authors quoted have witnessed their transfer, unlike cases of killing a person. Larson (1986:127) writes for the Ilaga, "The . . uak payment consisted of 30 to 35 small live pigs and an equal number of wealth objects, including chunks of salt ash . . . cowrie shell strings . . . and steel axe heads . . . together with many items of lesser value such as steel knives . . . and individual cowries." For the Mulia, Hayward (1997:141) states, "Such a payment typically consists of gifts of 7-8 pigs, 2-3 sacred stones and perhaps 18-20 shell bands," and for the Konda, O'Brien (1969a:220) calculated very similar amounts. There, the uak included an average of 8.1 pigs, 2.3 stones, 18.9 shell bands, 2.1 "other items," 12.3 nets, and 7.0 balls of braid. The averages were based on seven uak. For Wanggulam, on the basis of nine uak, I calculated an average of 2.9 pigs, 29 ye, 20.5 shell bands, and 0.6 steel implements (Ploeg 1969:28). Notwithstanding the similarities in the figures that Hayward and O'Brien reported, it should be noted that Mulia and Konda were separated by an area where ye exchange stones were not in use.

If the actual composition of the payments followed preference, then pigs got the highest rating among the Ilaga Dani. It is also noteworthy that in Ilaga the uak contained live pigs (Larson 1986:127). Among the Wanggulam, pigs were killed while the uak was assembled and their meat distributed first to the contributors to the uak, and one or a few days later to the relatives of the groom who welcomed the bride to his hamlet. However, among the Ilaga Dani, it seems pigs were transferred live and presumably, like the other items of the uak, given to those who a generation earlier had contributed to the uak for the bride's mother. The Wanggulam payments included by far the smallest number of pigs. Notable also is the comparatively large number of ye in the Wanggulam payments.

Western Dani groups appear to have categorized wealth items in dissimilar ways. Like the Wanggulam, the Konda Valley Dani distinguished between male and female ye (O'Brien 1969b:408). However, Hayward writes that Mulia Dani "sacred stones" did not show the male and female forms of Wanggulam and Konda Valley ye, and that the Mulia Dani denied that they categorized their ye in this way (Hayward 1997:112, 127n1). I also do not know whether other Western Dani regarded the ye of their wedding payments as representations of the bride's body parts. The North Baliem Dani at Tiom seem to have graded or ranked their cowries. They delighted in seeing valuable specimens (Draper 1958:29).

\section{Ritual Wealth}

Ethnographers have reported the existence of inalienable ritual wealth items among all Western Dani groups which have been investigated. Since these objects 
were discarded soon after Europeans had settled among them, only Larson, an early settler, provides a description that seems to be based on actual observation. Larson (1986:68, 71-73) writes that a range of objects were associated with the ancestors: string nets and arm bands to which were tied hundreds of pig tails, belts and necklaces set with cowries and other shells, and "large smooth stones," to some of which "a tail and shell pair" had been attached. These were kept in closets in men's houses or in a special "war house" (Larson 1986:72). During large rituals, these objects were laid out on banana leaves and/or worn during dances. The stones were the object of cleansing rites, apparently especially or only during male initiation. Larson does not discuss the ownership of these objects, but it seems plausible that objects associated with ancestors were held by some or all of their descendants. Reports of other Western Dani groups, based on oral information, suggest close similarities (Hayward 1997:109-10; Maynard, quoted in Hayward 1980:137; O'Brien 1969b:90). Some of these objects were personally owned (Hayward 1980:137). In addition, he refers to the prominence of the ancestor cult, also in Mulia (Hayward 1997:145). However, O'Brien is silent on this matter, although she discusses ghosts and spirits. My data do not suggest the prominence of such a cult. So in this respect there seems to have been variety among the Western Dani.

\section{GRAND VALLEY DANI}

In contrast to the Western Dani, most Grand Valley Dani were averse, if not actively opposed, to the influence of administrators and missionaries. The mass conversion of the Western Dani around 1960, stopped at the northwestern tip of the Grand Valley, where the Baliem River enters it, suggesting a sharp cultural boundary and important cultural differences between the two groups. Also, in the 1960s, missionaries had little success (Heider 1997:160). The first patrol post in the Grand Valley was set up in 1956 (Veldkamp 1996), and from 1958 the colonial administration attempted, often by force, to put an end to Dani warfare (Gonsalves and Verhoog 1999:67; Meiselas 2003:86-87). These efforts were hardly successful. Warfare persisted. Grand Valley Dani regarded warfare as a religious duty, a requirement for the support of the ancestral ghosts (Peters 1967:79-80, 1975:76; Broekhuyse 1967:217, 1996:103).

Grand Valley Dani polities were of much larger scale than those among the Western Dani. However, in several other respects they were similar. They focused inward, with a tendency toward endogamy among pairs of lineages, and with outside boundaries defined by permanent hostility and frequent wars with neighbors. In their descriptions of the Grand Valley Dani way of life, ethnographers have given more prominence to inalienable than to alienable wealth items; i.e., artifacts held as sacred items by lineages or subclans and not transferred to outsiders. These descriptions differ from the early Me and Western Dani ethnographies, where the emphasis is the other way around; i.e., on wealth items that are exchanged. 
In part, the difference is due to the bias of the ethnographers concerned. Since Peters, Broekhuyse, and Heider focused on religious life, long sections of their monographs consist of the description of rituals. However, as noted above, the different foci of the Western Dani and Central Dani ethnographies are also in part differences between their respective ways of life. Ritual seems to have been more important for Grand Valley Dani than for the Western Dani. For instance, in his 1970 monograph, Heider spends twenty pages on elaborate funeral ceremonies (Heider 1970:146-66). They included display of wealth items, and Heider intimates that this aspect of wealth item was more important than their exchange. Lemonnier (1991:19) writes that Grand Valley polities had Leaders, but in this case they were primarily masters of ceremonies and ritual rather than organizers of exchanges (see also Butt 2001:80, n. 1).

\section{Exchange Items}

The items that Grand Valley Dani exchanged were similar to those in circulation among the Western Dani; oblong polished stones, cowries set on looped bands, and carrying nets (Heider 1970:292). Many of the stones came from the same source as those with the Western Dani (Pétrequin and Pétrequin 1993:194-95), but their size was possibly larger. Many stones were decorated with feathers, fur, and items of female dress (Heider 1970:289), while Western Dani stones were bare, as I observed among the Wanggulam. Representing whole persons, they were laid down in a row and were subdivided into "bone" stones in the center and "leg" stones at both ends (Heider 1970:287), reminiscent of the Wanggulam notion that they represented human body parts. The nets included strapless ones (Heider 1970:151) and long, rectangular nets, open along two sides, which are usually reserved for funeral exchanges. Such nets have not been reported for the Western Dani. It is noteworthy that the volume of items exchanged at funerals seems to have been larger than at weddings. This feature is associated with the prevalence of the ancestor cult among the Grand Valley Dani (Ploeg 2001). Wedding payments were linked across the generations (Heider 1972:180), again reminiscent of the Western Dani. Whether the bride's father's payment had to equal that for the bride's mother remains unclear. Heider's (1972:180) table of marriage prestations indicates that pigs and pork on the one hand, and stones, shell bands, and nets on the other, moved in opposite directions during the exchanges. This did not occur to the same extent among Western Dani.

Heider (1997:163-64) remarks that a young man in the northeast Grand Valley in 1988 had remained a bachelor since he was unable to assemble the pigs and shells needed for bridewealth. So in this part of the valley, bridewealth was still to be paid and shells were part of it. At that time, Indonesian money was in circulation in the Grand Valley (unpublished report by Naylor, quoted in Meiselas 2003:128), and by then the Me had abandoned their cowries. 


\section{Ritual Wealth Items}

It is useful to divide inalienable wealth items among the Grand Valley Dani into two or three categories. One consists of artifacts, especially the sacred stones, held by groups of men and kept in the men's houses. A second is of similar sacred artifacts held in war men's houses, thus called on account of either the special sacred stones held there (Peters 1967:82, 1975:80) or the prominent war leaders living there (Heider 1970:85; Broekhuyse 1967:98, 122-25). A third category consists of personal possessions, especially the amulets (tipat) that men and women wore for protection. Whether these are inalienable goods, in the sense used by Weiner and Godelier, is uncertain, since these authors refer primarily to goods held by groups. The amulets were consecrated in group ritual (Heider 1972:192; Peters 1967:143-45, 1975:15153; Broekhuyse 1967:108-12, 141). Broekhuyse (1967:111) writes, "The great significance of the tipat is made clear by the fact that one finds it round the neck of almost every man and every initiated boy [pace Peters (1967:144, 1975:151-52) who reports that also women and girls wear one]. They do not want to give them up." I have found no reference to what happened to the tipat when a person died and was cremated.

Ganekhe were stones similar to exchange stones and very prominent sacred possessions. Like the Grand Valley exchange stones, they were provided with wrappings (Broekhuyse 1967:100-01). They included other kinds of objects, like shell bands, and Broekhuyse reports the occurrence of one made of bone found under mysterious circumstances and believed to have been left behind by a ghost. Subsequently, a cowrie believed to date back to the ancestors had been fastened to it. Ganekhe were associated with ancestral ghosts and were on occasion refurbished (Peters 1967:112, 151-59, 1975:115, 160-72; Broekhuyse 1967:102), as happened during a ritual in the presence of male lineage members. Pigs were slaughtered, and the ganekhe were rubbed with pig fat. During such a ritual, Peters (1967:152-59, 1975:161-72) observed the wrappings to be renewed, and two men uttered spells.

Ethnographers disagree about ganekhe ownership. Heider (1970:25) says that individual men owned them and might take them when they moved to another men's house. Broekhuyse (1967:98), however, maintains that they were common property of "the members of one . . . lineage or local clan." He admits exceptions, and mentions a man who regarded one as his "personal" ganekhe (Broekhuyse 1967:100). Hampton (1999:127-28) insists that the ganekhe were owned by individual men. However, more important than the matter of ownership seems to be the fact that ganekhe ritual was to benefit the group. On this the early authors agree.

The second category of inalienable possessions also consisted of ganekhe that were kept in the war men's houses for the ancestors killed in hostilities (Peters $1967: 159-60,1975: 173)$. Of these there was one per lineage (Peters 1967:82, 1975:80). It seems that the ritual of refurbishing the war ganekhe took longer than that for other ganekhe, and included consecration of new neck amulets. A greater number of pigs was killed and eaten. For one day, working the land was forbidden, 
and even pigs were kept in their sties. The ritual was directed toward success in war, while the ritual refurbishing the ganekhe held in the other men's houses was for the welfare people hoped to obtain from their ancestors (Peters 1967:88-101, 151-52, 1975:87-102, 160-61).

When Heider returned briefly to the northeast Grand Valley in 1988, warfare there had ceased and men's houses had become accessible to women (Heider 1997:159). Whereas Heider intimates that the ancestral stones had lost their potency, Hampton's subsequent observations, made where Heider had conducted his field research, suggest otherwise. In 1989, or possibly a little later, Hampton (1999:145) attended a ritual refurbishing of ganekhe, and his description makes it clear that the ritual had changed little from the early 1960s, when the earlier ethnographers carried out their field research. By the mid-1990s, such rituals included the veneration of ganekhe, and had "replaced warfare as the key way to control the actions of ancestors” (Butt 1998:77-81).

\section{Pigs and Pork}

Pigs and pork were essential in all Grand Valley rituals. Pork might be given as a welcoming gift, or as the acknowledgment of a gift that remained to be reciprocated (cf. Lemonnier 1993:37; Ploeg 2001:35-36). Consuming pork was part of ritual, whether done communally (Heider 1997:123) or as an indicator of an individual's role in the ritual (Peters 1967:89, 94-95, 1975:88, 94-95). In any case, which parts persons were given (e.g., fat, bacon, entrails, organs, head, and so on) had special significance. As the ethnographers focused on rituals, it is not clear whether the consumption of pork in rituals entailed gift transactions. The nonconsumable parts of pigs (i.e., tails, bones, and teeth) were retained to serve as tools, finery, and ritual objects (Heider 1970:55). It is clear that pigs formed part of marriage and compensation payments (Heider 1972:180, 183-84).

\section{DISCUSSION}

At an early stage of research in the Highlands, Brookfield (1964:33) noticed the differential agricultural potential of highland areas across New Guinea. Much later, Feil (1987:14-18) and Modjeska (1991:251) argued that these differences facilitated the emergence of Big Man leadership and Big Man economics. Such a development did take place in the Paniai-Tage and Kamu-Tigi areas, but not in the Grand Valley, where agricultural intensification occurred. Of the peoples considered in this essay, the Me conformed most closely to Godelier's model, although they live farthest away from Papua New Guinea. The contrast that Hylkema (2002) noted between, on the one hand, the Paniai-Tage and the Kamu-Tigi versions of the Me way of life and, on the other, the Mapia version, suggests a transformation away from a time when agricultural intensification was of minor importance and animal food was obtained 
primarily by hunting and fishing. As in the Highlands of Papua New Guinea, the transformation may have started before the introduction of the sweet potato.

The Grand Valley Dani deviated most from the Great Man-Big Man model, since they used their increased productive capacity (and the resulting increase in wealth items) to maintain or intensify their ancestor cult, rather than build a network of exchange relations. They were most interested in the stones used for ritual purposes. The Western Dani, however, were keenly interested in acquiring the cowries administrative officers and missionaries brought (Ploeg, In press), and held onto them after discarding their exchange stones and ritual objects.

The wealth items used by Me, Western Dani, and Grand Valley Dani were largely similar, but the Me did not use the polished stone blades, even though many lived not much further away from the quarries than did the Western Dani and the Grand Valley Dani. This seems to be another instance of the selectivity with which Me met new opportunities; e.g., they adopted tobacco; many, but not all, adopted the sweet potato as their staple; and they did not adopt maize. If Hylkema is correct in stating that the import of cowries among the Me had sharply increased before Europeans settled among them, the desire for these shells may have induced them to step up production, especially of pigs, to obtain them. The Me used wealth items not only to build and maintain a wide network of gift relations, but also to transact with each other on a casual basis. Possibly they did so also with a view toward the gift relations in which they were, with the once-only transactions, for profit or to obtain a good needed for a gift, subsidiary to gift exchanges. They also availed themselves of the opportunities their grading of cowries provided them to pressure their partners to upgrade their prestations.

While all three peoples had pigs as wealth items, they used them for different purposes. For the Me, pigs were an important means to collect cowries. The Western Dani used them primarily as alienable gift items, as ingredients of gifts. They also used them for ritual purposes, but due to the early mass conversions to Christianity, what and how varied these uses were among the Western Dani groups is unknown. The Grand Valley Dani used pigs primarily for rituals in their ancestor cult and their pig feast.

The variety of uses for similar objects points to the variety in significance that people accorded these objects. In contrast, similar significance also can be accorded to different objects. For example, the gradations in value that the Paniai-Tage and the Kamu-Tigi Me attributed to cowries resemble the gradations in value which Wanggulam accorded their exchange stones, and the positioning of shells of different value in the Me shell strings resembles the positioning of exchange stones in the layout of a Wanggulam ceremonial payment.

Weiner (1992:43) argues that alienable and inalienable possessions are linked in that some objects are given away while others are held. "What motivated reciprocity is . . . the desire to keep something back from the pressures of give and take. This something is a possession that speaks to and for an individual's or a group's social identity and, in so doing, affirms the difference between one person or group and 
another." Godelier's (1999:36) view is that gift exchange does not operate in a void, but has to be rooted: "There is always, in every human activity if it is to become constituted, something that precedes exchange and in which exchange takes root, something that exchange both alters and preserves, extends and renews at the same time." Godelier improves Weiner's formulation, which applies well to the Grand Valley Dani, where the ancestor cult provided the context for death and compensation payments. By implication, the formulations apply also to the Western Dani because their exchange stones lost value soon after they had discarded their wealth items that, presumably, had been inalienable. However, they apply much less to the Me, whose cowrie transactions apparently were not rooted in an ideology made manifest in inalienable wealth items. In this respect, too, the cultural differences between the three ethnic groups are apparent.

Finally, I return to Hyndman and Morren's (1990) notion of the Western Sphere of the Central Highlands. The area concerned stands out in several respects. Population density is high compared to the surrounding areas, and the scale of linguistic and political groups is large (Ploeg 2001). Hyndman and Morren (1990) posit that groups having a single sphere as their habitat share a common tradition, but Western Highlands groups do not. Admittedly, many claim to have originated from the same area, the southeast of the Grand Valley, but at the time of first contact, the inhabitants of this area, the Grand Valley Dani, did not exert a strong influence on the people who had moved away. On the contrary, it seems likely that one of the migrating groups, the Western Dani, had exerted such an influence on the groups that they encountered during their west and northward expansion. The inhabitants of the western part of this Western Sphere, especially the Moni and the Me, claim origin from the east, but in my view represent separate ways of life that were growing apart.

\section{NOTES}

1. This article was originally presented at the 2001 and 2002 meetings of the Association for Social Anthropology in Oceania (ASAO) in the session, "Transformations of Exchange Systems." I thank the participants in the session, especially Paula Brown Glick, one of the conveners, for their stimulus. I also thank the anonymous reviewers of Ethnology and John A. Barnes for their instructive comments on the penultimate draft of the article. This article contains several quotations from Dutch publications, all translated by me.

2. Pouwer, who worked on the south coast in the early 1950s, supports Hylkema's view (pers. comm.).

3. What goes against his interpretation of the term abstraction is that Godelier makes its meaning clear by referring to the curved boar tusks used as wealth items in several parts of Melanesia. These tusks, however, are a reminder of successful productive activities, if not successful management of life force. 4. The Wodani, like the Me, employed pigs and cowries as their main wealth items. Cowries were a general medium of exchange, and for that reason Breton (1999:558) considers them as "money in the strictest sense." Yet the Wodani also regarded each shell "as an individual, a unique piece in its own right," and they gave names to the most precious ones (Breton 1999:559-61, 2002). As regards these two features, Wodani money differs from Western money. Further, Wodani conceive of cowries as "perpetual persons who are the instruments of human reproduction" (Breton 1999:567).

5. I am grateful to Dr. Eric Venbrux for drawing my attention to Peterson's paper. 
6. C. Ballard (pers. comm) links the location of salt wells with the direction of migrations. The Amungme south of the main ranges kept the location of their salt wells hidden from the Dani to keep them away.

7. Hayward (1980:137) quotes from a letter that Maynard, an eyewitness to the burnings, sent to the office of the Unevangelised Fields Mission. The letter lists the objects burned: "innumerable bows, arrows, spears, stone and bone knives, shells, beautiful fur headdresses, pig tails, nose bones, bits of string, all sorts and sizes of feathers, large and small bridal stones, pieces of cane, armbands, 'feather dusters' (large feather affairs used for waving about to chase evil spirits), necklaces, rare ornamental shell plus a host of wrapped items which we didn't see."

\section{BIBLIOGRAPHY}

Boelen, K. W. J. n.d. (1955). Dokter aan de Wisselmeren. Baarn.

Breton, S. 1999. Social Body and Icon of the Person: A Symbolic Analysis of Shell Money among the Wodani, Western Highlands of Irian Jaya. American Ethnologist 26:558-82.

2002. Tuer, manger, payer: L'alliance monétaire des Wodani de Papouasie occidentale. Questions de Monnaie. L'Homme 162:197-229.

Broekhuyse, J. Th. 1967. The Wiligiman-Dani. Een Cultureel-Anthropologische Studie over Religie en Oorlogvoering in de Baliem-vallei. Tilburg.

1996. De Harvard-Peabody-Expeditie in de Baliemvallei. Besturen in Nederlands-NieuwGuinea 1945-62, ed. P. Schoorl, pp. 129-49. Leiden.

Brookfield, H. C. 1964. The Ecology of Highland Settlement: Some Suggestions. New Guinea: The Central Highlands, ed. J. B. Watson. American Anthropologist 66(4):20-38.

Butt, L. 1998. The Social and Political Life of Infants among the Baliem Valley Dani, Irian Jaya. Unpublished Ph.D. dissertation, McGill University. Montreal.

2001. "K. B. Kills": Political Violence, Birth Control, and the Baliem Valley Dani. The Asia Pacific Journal of Anthropology 2:63-86.

Campbell, S. F. 1983. Kula in Vakuta: The Mechanics of Keda. The Kula: New Perspectives on Massim Exchange, eds. J. R. Leach and E. Leach, pp. 201-27. Cambridge.

de Bruijn, J. V. 1978. Het Verdwenen Volk. Bussum.

Defert, G. 1996. L'Indonésie et la Nouvelle-Guinée-Occidentale: Maintien des Frontières Coloniales ou Respect des Identités Communautaires. Paris.

Draper, N., and S. Draper (eds). 1990. Daring to Believe: Personal Accounts of Life Changing Events in Papua New Guinea and Irian Jaya. Hawthorn VIC.

Draper, S. 1958. Summary. North Baliem Customs. Unpublished manuscript.

Dubbeldam, L. F. B. 1964. The Devaluation of the Kapauku-Cowrie as a Factor of Social Disintegration. American Anthropologist 66(4):293-303.

Ellen, R. 2003. On the Edge of the Banda Zone: Past and Present in the Social Organization of a Moluccan Trading Network. Honolulu.

Feil, D. K. 1987. The Evolution of Papua New Guinea Highlands Societies. Cambridge.

Foster, R. J. 1999. In God We Trust? The Legitimacy of Melanesian Currencies. Money and Modernity: State and Local Currencies in Melanesia, eds. D. Akin, and J. Robbins, pp. 21431. Pittsburgh.

Giay, B. 1995. Zakheus Pakage and His Communities: Indigenous Religious Discourse, Socio-Political Resistance, and Ethnohistory of the Me of Irian Jaya. Amsterdam.

Godelier, M. 1982. Social Hierarchies among the Baruya of New Guinea. Inequality in New Guinea Highlands Societies, ed. A. Strathern, pp. 3-24. Cambridge.

1991. An Unfinished Attempt at Reconstructing the Social Processes Which May Have Prompted the Transformation of Great Men Societies into Big Men Societies. Big Men and Great Men: Personifications of Power in Melanesia Godelier, eds. M. Godelier and M. Strathern, pp. 274-304. Cambridge. 
1996. L’Énigme du Don. Paris.

1999. The Enigma of the Gift, transl. N. Scott. Chicago.

Gonsalves, R. A., and G. J. Verhoog. 1999. Mr. Gonsalves: Memoires. Amsterdam.

Gregory, C. A. 1982. Gifts and Commodities. London.

Hampton, O. W. 1999. Culture of Stone: Sacred and Profane Uses of Stone among the Dani. College Station TX.

Hayward, D. J. 1980. The Dani of Irian Jaya before and after Conversion. Sentani, West Papua.

1997. Vernacular Christianity among the Mulia Dani: An Ethnography of Belief among the Western Dani of Irian Jaya. Lanham MD.

Heider, K. G. 1970. The Dugum Dani. A Papuan Culture in the Highlands of West New Guinea. Viking Fund Publications in Anthropology 49. New York.

1972. The Grand Valley Dani Pig Feast: A Ritual of Passage and Intensification. Oceania 47:169-97.

1997. Grand Valley Dani: Peaceful Warriors. New York.

Hughes, I. 1977. New Guinea Stone Age Trade: The Geography and Ecology of Traffic in the Interior. Terra Australis 3. Canberra.

Hylkema, S. 1974. Het grote varkensfeest. De juwo in de praktijk onderzocht op zijn existentiële betekenis in de Ekagi-samenleving. Unpublished manuscript.

2002. Paniyai, Kamu-Tigi and Mapiya, Paniai District, Papua, transl. A. Ploeg. Bijdragen tot de Taal-, Land- en Volkenkunde 158:225-52.

n.d.a. Untitled manuscript dealing with the role of cowrie shells among the Me.

n.d.b. Untitled manuscript dealing with marriage payments among the Me.

Hyndman, D., and G. E. B. Morren, Jr. 1990. The Human Ecology of the Mountain-Ok of Central New Guinea: A Regional and Inter-Regional Approach. Children of Afek: Tradition and Change among the Mountain-Ok of Central New Guinea, eds. B. Craig and D. Hyndman, pp. 9-26. Sydney.

Klamer, A., and H. van Dalen. 1998. Het Verhaal van Geld. Amsterdam.

Kopytoff, I. 1986. The Cultural Biography of Things: Commoditization as Process. The Social Life of Things: Commodities in Cultural Perspective, ed. A. Appadurai, pp. 64-91. Cambridge.

Larson, G. F. 1986. The Structure and Demography of the Cycle of Warfare among the Ilaga Dani of Irian Jaya. Draft Ph.D. dissertation, University of Michigan.

Lederman, R. 1991. "Interests" in Exchange: Increment, Equivalence and the Limits of Big-Manship. Big Men and Great Men: Personifications of Power in Melanesia, eds. M. Godelier and M. Strathern, pp. 215-33. Cambridge.

Lemonnier, P. 1990. Guerres et festins: Paix, échanges et competition dans les Highlands de NouvelleGuinée. Paris.

1991. From Great Men to Big Men: Peace, Substitution and Competition in the Highlands of New Guinea. Big Men and Great Men: Personifications of Power in Melanesia, eds. M. Godelier and M. Strathern, pp. 7-27. Cambridge.

1993. Le porc comme substitut de vie; formes de compensation et échanges en NouvelleGuinée. Social Anthropology 1:33-55.

Mauss, M. 1990. The Gift. The Form and Reason for Exchange in Archaic Societies, transl. W. D. Halls. London.

Meiselas, S. 2003. Encounters with the Dani: Stories from the Baliem Valley. New York.

Modjeska, N. 1991. Post-Ipomoean Modernism: The Duna Example. Big Men and Great Men: Personifications of Power in Melanesia, eds. M. Godelier and M. Strathern, pp. 234-55. Cambridge.

O'Brien, D. A. 1969a. Marriage among the Konda Valley Dani. Pigs, Pearshells and Women: Marriage in the New Guinea Highlands, eds. R. M. Glasse and M. J. Meggitt, pp. 198-234. Englewood Cliffs NJ. 
1969b. The Economics of Dani Marriage: An Analysis of Marriage Payments in a Highlands New Guinea Society. Unpublished Ph.D. dissertation, Yale University. New Haven.

O'Brien, D. A., and A. Ploeg 1964. Acculturation Movements among Western Dani. American Anthropologist 66(4):281-92.

Peters, H. L. 1967. Enige Hoofdstukken uit het Sociaal-Religieuze Leven van een Dani Groep. Venlo. 1975. Some Observations of the Social and Religious Life of a Dani group, transl. G. P. Resink. IRIAN: Bulletin of Irin Jaya Development 4(2).

Peterson, N. 1993. Demand Sharing: Reciprocity and the Pressure for Generosity among Foragers. American Anthropologist 95:860-74.

Pétrequin, P., and A.-M. Pétrequin. 1993. Écologie d'un Outil: Le Hache de Pierre en Irian Jaya (Indonésie). Centre National de la Recherche Scientifique, Monographie du CRA 12. Paris.

Ploeg, A. 1969. Government in Wanggulam. Verhandelingen van het Koninklijk Instituut voor Taal-, Land- en Volkenkunde 57. The Hague.

2001. The Other Western Highlands. Social Anthropology 9:25-43.

_ In Press. Wealth among the Western Dani, West Papua. Exchange and Sacrifice: Papers in Honour of Daniel de Coppet, eds. P. Stewart and A. Strathern.

Pospisil, L. 1958. Kapauku Papuans and Their Law. New Haven.

1963. Kapauku Papuan Economy. New Haven.

1978. The Kapauku Papuans of West New Guinea. New York.

1989. Traditional Egalitarian Society, Its Loose Structure, Emerging Inequality and Other Widely Held Myths. Peoples on the Move: Current Themes of Anthropological Research in New Guinea, eds. P. Haenen and J. Pouwer, pp. 18-30. Nijmegen.

Robbins, J., and D. Akin. 1999. An Introduction to Melanesian Currencies: Agencies, Identity, and Social Reproduction. Money and Modernity: State and Local Currencies in Melanesia, eds. D. Akin and J. Robbins, pp. 1-40. Pittsburgh.

Rutherford, D. 2003. Raiding the Land of the Foreigners: The Limits of the Nation on an Indonesian Frontier. Princeton NJ.

Silzer, P. J., and H. Heikkinen Clouse. 1991. Index of Irian Jaya Languages. IRIAN: Bulletin of Irian Jaya.

Strathern, A. 1971. The Rope of Moka: Big-Men and Ceremonial Exchange in Mount Hagen, New Guinea. Cambridge.

Szalay, A. 1999. Maokop. The Montane Cultures of Central Irian Jaya: Environment, Society and History in Highland West New Guinea. Unpublished Ph.D. dissertation, University of Sydney.

Uberoi, J. P. S. 1962. Politics of the Kula Ring: An Analysis of the Findings of Bronislaw Malinowski. Manchester.

Umbreit, M. H., F. H. Elgin, and C. V. Kinter. 1948. Fundamentals of Economics. New York.

van Baal, J. 1989. Ontglipt Verleden. Vol. 2. Leven in Verandering: 1947-1958. Franeker.

van Rhijn, M. 1969. Een Endemie van Struma en Cretinisme in het Centrale Bergland van West Nieuw-Guinea. Zaltbommel.

Veldkamp, F. 1996. De bestuurlijke dilemma's bij de openlegging van de Baliem. Besturen in Nederlands-Nieuw-Guinea 1945-62, ed. P. Schoorl, pp. 73-116. Leiden.

Watson. J. B. (ed.). 1964. New Guinea: The Central Highlands. American Anthropologist 66(4).

Weiner, A. 1992. Inalienable Possessions: The Paradox of Keeping-While-Giving. Berkeley.

Wiessner, P., and A. Tumu. 1998. Historical Vines: Enga Networks of Exchange, Ritual and Warfare in Papua New Guinea. Washington DC.

Wirz, P. 1924. Anthropologische und Ethnologische Ergebnisse der Central Neu-Guinea Expedition 1921-2. Nova Guinea 16. 